\title{
Common mental disorders in medical students: A repeated cross-sectional study over six years
}

\author{
Edméa Fontes de Oliva Costa ${ }^{1 *}$, Carlos Mauricio Cardeal Mendes ${ }^{2}$, Tarcísio Matos de Andrade $^{3}$ \\ ${ }^{1} \mathrm{MD}, \mathrm{MSc}, \mathrm{PhD}$, Adjunct Professor of Medicine at the Universidade Federal de Sergipe (UFS), PhD in the Program of Post-Graduate Medicine and Health at the Universidade Federal da Bahia (PPGMS/UFBA), \\ and Fellow of Foundation for Advancement International of Medical Education and Research (FAIMER-Br), Aracaju, SE, Brazil \\ ${ }^{2} \mathrm{MD}, \mathrm{MSc}, \mathrm{PhD}$, Biostatistic Professor at the PPGMS/UFBA, Salvador, BA, Brazil \\ ${ }^{3} \mathrm{MD}, \mathrm{MSc}, \mathrm{PhD}$, Associate Professor of Medicine at the PPGMS/UFBA, Salvador, BA, Brazil
}

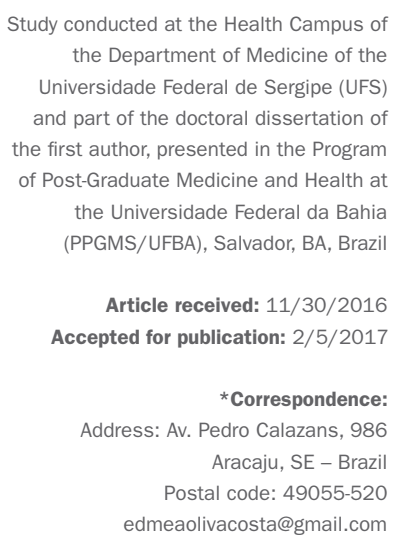

Article received: $11 / 30 / 2016$ Accepted for publication: 2/5/2017

*Correspondence: Address: Av. Pedro Calazans, 986 Aracaju, SE - Brazi Postal code: $49055-520$ edmeaolivacosta@gmail.com

http://dx.doi.org/10.1590/1806-9282.63.09.771

\section{SUMMARY}

Introduction: Becoming a medical doctor is a very complex process. Factors related to the student's personality, the educational process and the daily experience with death contribute to peculiar psycho-emotional experiences, not always properly investigated during medical training.

Objective: To estimate the prevalence of common mental disorders (CMD) and associated factors, over six years of medical undergraduate course among all students of a class at a public university in Brazil.

Method: Cross-sectional study based on repeated surveys. All 40 students enrolled in 2006 in the first year of our medical school were included and evaluated annually until 2011 using the SRQ-20 and a structured questionnaire prepared by the authors on sociodemographic, personal and educational aspects. We performed logistic regression and correspondence analysis.

Results: The 40 freshmen in the first evaluation had a mean age of 20 years $(\mathrm{SD}=2.4)$, $57.5 \%$ were female, and $41 \%$ were approved after taking their third entrance exam. The prevalence of CMD increased over the years: from $12.5 \%$ in the first year to $43.2 \%$ in the fifth. The following variables were potentially associated with CMD: female sex $(\mathrm{PR}=1.38)$, originating from capital cities $(\mathrm{PR}=1.97)$, the program was less than they expected $(\mathrm{PR}=3.20)$, discomfort with program activities $(\mathrm{PR}=2.10)$, dissatisfaction with teaching strategies ( $\mathrm{PR}=1.38$ ), and feeling that the program is not a source of pleasure ( $\mathrm{PR}=2.06$ ), being $\mathrm{R} 2=28.8 \%$ and $\mathrm{AIC}=60.04$.

Conclusion: The factors potentially associated with the high prevalence of CMD were those related to medical training, showing that it is necessary to implement preventive measures and review the educational process in order to reduce the damages caused by the development of CMD.

Keywords: mental disorders, medical students, mental health, medical education, occupational health.

\section{INTRODUCTION}

Common mental disorders (CMD), also known as minor psychiatric disorders, are mild psychic troubles that may cause large biopsychic social impact over many years. CMD do not match the formal criteria for depression and/or anxiety diagnoses according to Diagnostic and Statistical Manual of Mental Disorders-Five Edition (DSM-V) and International Classification Disease- $10^{\text {th }}$ Revision (ICD-10), although they are an important public health problem given the limitations they cause, which range from impaired work performance to the potential development of more serious mental disorders. These limitations reflect the importance of identification and early intervention for CMD. ${ }^{1}$ The prevalence of this disorder varies from 7 to $22 \%$ in the populations of industrialized countries and from 22 to $51.6 \%$ in Brazil. ${ }^{2-6}$

Becoming a medical doctor is a highly complex process. Factors related to the student's personality that motivate their professional choice, the educational process and daily experience with pain and death inherent to the craft contribute to peculiar psycho-emotional experiences that are not always adequately investigated 
during medical training. Stress among medical students appears to be a serious problem, which increases the likelihood of a CMD.

An increased prevalence of mental disorders is noted early in medical students, as indicated by various works published in Brazil and in other countries. Unfortunately, only a limited number of longitudinal or follow-up studies are available. ${ }^{7-11}$ Among Brazilian medical students, the prevalence of CMD varies from 31.7 to $44.7 \%{ }^{9-15}$

Permanent research on mental disorders among medical students and critical reflection by medical schools regarding their role in the promotion and prevention of these disorders will help train physicians to be healthier and emotionally better prepared to help diminish the health problems of the people they assist. Thus, our study aims to estimate the prevalence of CMD, associated factors, their changes and movements over the course of six years of the medical undergraduate course among students of a class at a public university in northeastern Brazil. This is a novelty because there are no previous studies including a population with these characteristics. It also aimed to propose preventive measures, if needed.

\section{Method}

\section{Setting}

Our study was conducted at a public university in northeastern Brazil. The program was offered to 40 students per semester in 2006. The students were selected through a difficult entry exam.

The program is based on a traditional teaching method of 12 semesters divided into three cycles: Basic Sciences ( $1^{\text {st }}$ to $4^{\text {th }}$ semesters), Introductory Clinical Cycle $\left(5^{\text {th }}\right.$ to $9^{\text {th }}$ semesters), and Internship (10 $10^{\text {th }}$ to $12^{\text {th }}$ semesters $)$.

\section{Researched population}

All 40 medical students enrolled in the first semester of 2006 (2006/1 class) were surveyed in this study.

\section{Pilot study}

We conducted a previous pilot study with the students enrolled in 2005 aiming to control the quality, train research assistants in data collection and refine the instruments to be applied after this study, particularly regarding language and the students' receptivity.

\section{Study design and data collection}

This is not a cohort study, since we chose not to identify the participants, consequently obtaining more true answers and improving respondent adherence.
The authors conducted a repeated inquiry crosssectional study with all 40 medical students of the class of 2006/1. The students were annually researched through two instruments applied in the classroom from 2006 to 2011. The researchers asked the professors for permission to apply the questionnaires during class.

Therefore, we were not able to separate those already diagnosed with CMD in order to exclusively follow the healthy individuals.

We decided to collect data annually instead of semiannually to avoid information accuracy bias because the instruments we used tended to not detect the disorder when the respondent was annoyed by the repetition.

\section{Research instruments}

We used two self-administered questionnaires. One was created by the authors and tested in the pilot study conducted in 2005. The questionnaire contained 54 pre-coded closed questions on socialdemographic characteristics, the educational process and personal aspects related to career choice, and the psycho-emotional experiences of each respondent. The other assessment was the Self-Reporting Questionnaire (SRQ-20) by the World Health Organization (WHO) for the "screening" of CMD in populations during primary attention. This questionnaire contains a rating scale for the following symptoms: anxiety, depressive and somatoform. ${ }^{16}$ It is a self-administered instrument validated for application in Brazil, with satisfactory levels of sensitivity (89\%), specificity ( $81 \%)$, positive predictive value $(81 \%)$, negative predictive value (82\%) and misclassification (19\%). ${ }^{2}$

The SRQ-20 comprises 20 questions with binary responses. For our study, we considered the last 30 days. Students with a score $\geq 6$ points for men and $\geq 8$ points for women were considered probable cases. The cut-off point in our research was determined based on the original work by Mari and Williams, ${ }^{2}$ other studies on medical students in Brazil, and the pilot study cited above., ${ }^{2,13,15}$

The association of the dependent variable (CMD) with the explanatory variables was investigated by calculating the adjusted prevalence ratio (PR) for the fifth year, which is the period with the highest prevalence of CMD.

The students' privacy was assured during data collection by placing the students far from one another in the classroom after being informed about the study and introduced to a staff member to clarify doubts regarding the questionnaires.

\section{Data analysis}

First, we described the population using descriptive statistics, followed by a simple analysis and construction of 
tables. Then, we performed the multiple analysis of correspondence with canonical normalization for the evaluation of the geometric relationships in the Chi-square distances of the studied variable contingencies in a multifactorial and multidimensional context. Next, we conducted a Poisson regression with a link "log" for the fifth year of the program applying the $\mathrm{R}$ program. ${ }^{17,18}$ Since the entire population was the target of this study, we did not perform inferential statistics. Thus, given the nonprobabilistic sampling plan, an estimate of robust variance based on the Sandwich estimative was not necessary.

We chose as inclusion criterion for the Poisson regression model to select only those variables that were most visually evident in the matching map - nearer to the outcome variable (CMD.yes): expectations regarding the program (ep), thoughts of dropping out of the university (dos), physical activities (pha), feelings about program activities (fa), steady partner (sp), emotional support (es), academic performance (ap), satisfaction with teaching strategies (ste), other occupation (occ), shares the burden of difficulties with someone (dd), place of origin (pr), sex (sx), religion (rel), medical program as a source of pleasure (mpsp). The criterion used to infer an association between $\mathrm{CMD}$ and these predictor variables was to consider only the variables that remained in the final regression model with adjusted $O R>1.35$.

\section{Ethical considerations}

This study was approved by our institutional ethics committee for human research (CAAE: 0018.0.107.000-06). The study participants signed a confidentiality agreement authorizing the disclosure of data but concealing their identity throughout the study period, including that involving the completion of questionnaires.

\section{Results}

Of the 40 students enrolled in the study (2006/1 class), one dropped out of the school, and another student failed the first year. In the subsequent years, some student losses were noted due to participation refusal. Of the participants, $17.9 \%$ entered in the first entry exam, $28.9 \%$ in the second exam, and $41 \%$ in the third exam, and $12.9 \%$ in the fourth or more exams.

The average age the students who joined the program was 20 years (standard deviation $=2.4$ ). In addition, $57.5 \%$ of the students were female, and $67.5 \%$ were from the state capital (Table 1).

Although $51.3 \%$ of the students reported having a physician in the family, only $2.7 \%$ said that their career choice was influenced by family members. Regarding their motivation for choosing the medical school, $54.1 \%$ reported a desire to help others.

The prevalence of CMD throughout the program was: $12.5 \%$ in the first program year $(\mathrm{n}=40$; data collected on the first day of school), $15.2 \%$ in the second year $(n=33)$, $33.3 \%$ in the third year $(n=36), 27 \%$ in the fourth year $(n=37), 43.2 \%$ in the fifth year $(n=37)$ and $24.32 \%$ in the sixth year $(n=37)$. Mental disorder diagnosis by a psy-

TABLE 1 Distribution of students from the $1^{\text {st }}$ and $6^{\text {th }}$ year medicine program based on sociodemographic variables. Aracaju, SE, Brazil, 2011.

\begin{tabular}{|c|c|c|}
\hline Variables & $\begin{array}{l}1^{\text {st }} \text { Year } \\
N\end{array}$ & $\begin{array}{l}6^{\text {th }}-\text { Year } \\
N\end{array}$ \\
\hline Total & $40(100 \%)$ & $37(100 \%)$ \\
\hline Students mean age & 20.0 & 24.3 \\
\hline Standard deviation & 2.4 & 2.0 \\
\hline \multicolumn{3}{|l|}{ Sex } \\
\hline Female & $23(57.5 \%)$ & $20(54.1 \%)$ \\
\hline Male & $17(42.5 \%)$ & $17(45.9 \%)$ \\
\hline \multicolumn{3}{|l|}{ Religion } \\
\hline Yes & $29(72.5 \%)$ & $17(45.9 \%)$ \\
\hline No & $11(27.5 \%)$ & $20(54.1 \%)$ \\
\hline \multicolumn{3}{|l|}{ Place of origin } \\
\hline State capital & $27(67.5 \%)$ & $30(81.1 \%)$ \\
\hline Hinterland & $5(12.5 \%)$ & $5(13.5 \%)$ \\
\hline Other states & $8(20.0 \%)$ & $2(5.4 \%)$ \\
\hline \multicolumn{3}{|l|}{ Living arrangements } \\
\hline Relatives & $35(87.5 \%)$ & $33(89.2 \%)$ \\
\hline Friends/colleagues & $1(2.5 \%)$ & $2(5.4 \%)$ \\
\hline Alone & $4(10.0 \%)$ & $2(5.4 \%)$ \\
\hline \multicolumn{3}{|c|}{ Family income (Minimum wage) } \\
\hline 1 to 5 & $6(15.0 \%)$ & $3(8.1 \%)$ \\
\hline 6 to 10 & $9(22.5 \%)$ & $9(24.3 \%)$ \\
\hline 11 to 15 & $7(17.5 \%)$ & $8(21.6 \%)$ \\
\hline 16 to 20 & $7(17.5 \%)$ & $4(10.8 \%)$ \\
\hline Over 20 & $4(10.0 \%)$ & $6(16.2 \%)$ \\
\hline Do not know & $7(17.5 \%)$ & $7(18.9 \%)$ \\
\hline \multicolumn{3}{|c|}{ Has another occupation? } \\
\hline Yes & $5(12.5 \%)$ & $5(23.1 \%)$ \\
\hline No & $35(87.5 \%)$ & $32(76.9 \%)$ \\
\hline \multicolumn{3}{|l|}{ Steady partner } \\
\hline Yes & $13(32.5 \%)$ & $28(75.7 \%)$ \\
\hline No & $27(67.5 \%)$ & $9(24.3 \%)$ \\
\hline \multicolumn{3}{|c|}{ Presence of a physician in the family } \\
\hline Yes & $20(51.3 \%)$ & $18(48.6 \%)$ \\
\hline No & $19(48.7 \%)^{*}$ & $19(51.4 \%)$ \\
\hline
\end{tabular}


chiatrist reported by the students presented its highest frequency in the $5^{\text {th }}$ year of the program $(10.8 \%)$, followed by the $3^{\text {rd }}$ and $6^{\text {th }}$ years $(8.3 \%)$.

Dissatisfaction with the profession choice was less frequently reported and only mentioned by one student in the $3^{\text {rd }}$ and $4^{\text {th }}$ program year and by two students in the $5^{\text {th }}$ and $6^{\text {th }}$ program year. From the $3^{\text {rd }}$ program year on, over one third of the students reported considering the program was less than they expected; this number achieved its highest frequency in the $5^{\text {th }}$ program year at $47.2 \%$ (Table 2).

The correspondence analysis maps display the variables potentially associated with CMD in each year of the program. Thus, in the first two years that correspond to the Basic Sciences cycle, the following associated variables were noted: a) in the $1^{\text {st }}$ year, being female, having no steady partner, not practicing physical activities and not having emotional support (eigenvalue equal to 0.0128 and 0.005 , with corresponding inertia of $37.9 \%$ and $15 \%$, respectively, for the first and second dimensions); b) in the $2^{\text {nd }}$ year, not having a steady partner, having low performance, feeling uncomfortable with the program activities, and not being satisfied with the teaching strategies (eigenvalues equal to 0.0116 and 0.006 , with corresponding inertia of 32.2 and $17.8 \%$, respectively, for the first and second dimensions).

From the Introductory Clinical Cycle onward, we identified the following variables: a) in the $3^{\text {rd }}$ year, low performance, lack of emotional support, feeling uncomfortable about college activities, lack of physical activities, lack of a steady partner, thoughts of dropping out of the school, not feeling that the program is a source of pleasure

TABLE 2 Distribution of medical students from the 2 nd program year according to variables related to professional choice and the educational process. Aracaju, SE - Brazil, 2011*.

\begin{tabular}{|c|c|c|c|c|c|}
\hline Variables & $\begin{array}{l}2^{\text {nd }} \text { year } \\
\mathrm{N}\end{array}$ & $\begin{array}{l}3^{\text {rd }} \text { year } \\
\mathrm{N}\end{array}$ & $\begin{array}{l}4^{\text {th }} \text { year } \\
N\end{array}$ & $\begin{array}{l}5^{\text {th }} \text { year } \\
\mathrm{N}\end{array}$ & $\begin{array}{l}6^{\text {th }} \text { year } \\
N\end{array}$ \\
\hline Total & $33(82.5 \%)$ & $36(90.0 \%)$ & $37(92.5 \%)$ & $37(92.5 \%)$ & $37(92.5 \%)$ \\
\hline \multicolumn{6}{|l|}{ Satisfaction with career choice } \\
\hline Yes & $33(100 \%)$ & $34(97.1 \%)$ & $36(97.3 \%)$ & $35(94.6 \%)$ & $35(94.6 \%)$ \\
\hline No & - & $01(2.9 \%)$ & $01(2.7 \%)$ & $02(5.4 \%)$ & $02(5.4 \%)$ \\
\hline Missing & & 01 & & & \\
\hline \multicolumn{6}{|l|}{ Expectations regarding the program } \\
\hline As expected or more than expected & $27(81.8 \%)$ & $19(59.4 \%)$ & $22(61.1 \%)$ & $19(52.8 \%)$ & $19(55.9 \%)$ \\
\hline Less than expected & $06(18.2 \%)$ & $13(40.6 \%)$ & $14(38.9 \%)$ & $17(47.2 \%)$ & $17(44.1 \%)$ \\
\hline Missing & & & 01 & 01 & 03 \\
\hline \multicolumn{6}{|l|}{ Thoughts of dropping out of the school? } \\
\hline Yes & $03(9.1 \%)$ & $13(36.1 \%)$ & $11(29.7 \%)$ & $12(32.4 \%)$ & $14(37.8 \%)$ \\
\hline No & $30(90.9 \%)$ & $23(63.9 \%)$ & $26(70.3 \%)$ & $25(67.6 \%)$ & $23(62.2 \%)$ \\
\hline \multicolumn{6}{|l|}{ Academic performance } \\
\hline Bad/not so good & $11(33.3 \%)$ & $11(30.6 \%)$ & $09(24.3 \%)$ & $09(24.3 \%)$ & $09(24.3 \%)$ \\
\hline Good & $22(66.7 \%)$ & $25(69.4 \%)$ & $28(75.7 \%)$ & $28(75.7 \%)$ & $28(75.7 \%)$ \\
\hline \multicolumn{6}{|c|}{ Acquisition of skills to become a good physician } \\
\hline Yes & $24(72.7 \%)$ & $25(75.8 \%)$ & $29(82.9 \%)$ & $25(69.4 \%)$ & $28(77.8 \%)$ \\
\hline No & $09(57.3 \%)$ & $08(24.2 \%)$ & $06(17.1 \%)$ & $11(30.6 \%)$ & $08(22.2 \%)$ \\
\hline Missing & & 03 & 02 & 01 & 01 \\
\hline \multicolumn{6}{|l|}{ Satisfaction with teaching strategies } \\
\hline Yes & $11(33.3 \%)$ & $12(33.3 \%)$ & $11(29.7 \%)$ & $05(13.5 \%)$ & $11(29.7 \%)$ \\
\hline No & $22(66.7 \%)$ & $24(66.7 \%)$ & $26(70.3 \%)$ & $32(86.5 \%)$ & $26(70.3 \%)$ \\
\hline \multicolumn{6}{|l|}{ Feelings about program activities } \\
\hline Comfortable & $28(84.8 \%)$ & $24(68.6 \%)$ & $21(58.3 \%)$ & $14(38.9 \%)$ & $18(50.0 \%)$ \\
\hline Uncomfortable & $05(15.2 \%)$ & $11(31.4 \%)$ & $15(41.7 \%)$ & $22(61.1 \%)$ & $18(50.0 \%)$ \\
\hline Missing & & 01 & 01 & 01 & 01 \\
\hline
\end{tabular}

*The students of the first program year were excluded from the analysis of educational process variables, given that responses to the questionnaire were obtained on the first day of class. 
and dissatisfaction with the teaching strategies (eigenvalues equal to 0.0193 and 0.008 , with corresponding inertia of 39.5 and $18.1 \%$, respectively, for the first and second dimensions); b) In the $4^{\text {th }}$ year, the following variables were identified: considering the program less than they expected, not feeling that the program is a source of pleasure, feeling uncomfortable with the program activities, not being satisfied with the teaching strategies and having no doctor in the family (eigenvalues equal to 0.0140 and 0.005 , with inertia corresponding to 39.0 and $15.6 \%$, re- spectively, for the first and second dimensions); c) The following were noted in the $5^{\text {th }}$ year (assessed in the $9^{\text {th }}$ semester), which involves the transition to the internship - being female, being from the capital, the program being less than they expected, feeling uncomfortable with the program activities, dissatisfaction with teaching strategies and the program being a source of pleasure (eigenvalues equal to 0.0355 and 0.007 , with corresponding inertia of 58.0 and $12.9 \%$, respectively, for the first and second dimensions) (Figure 1).

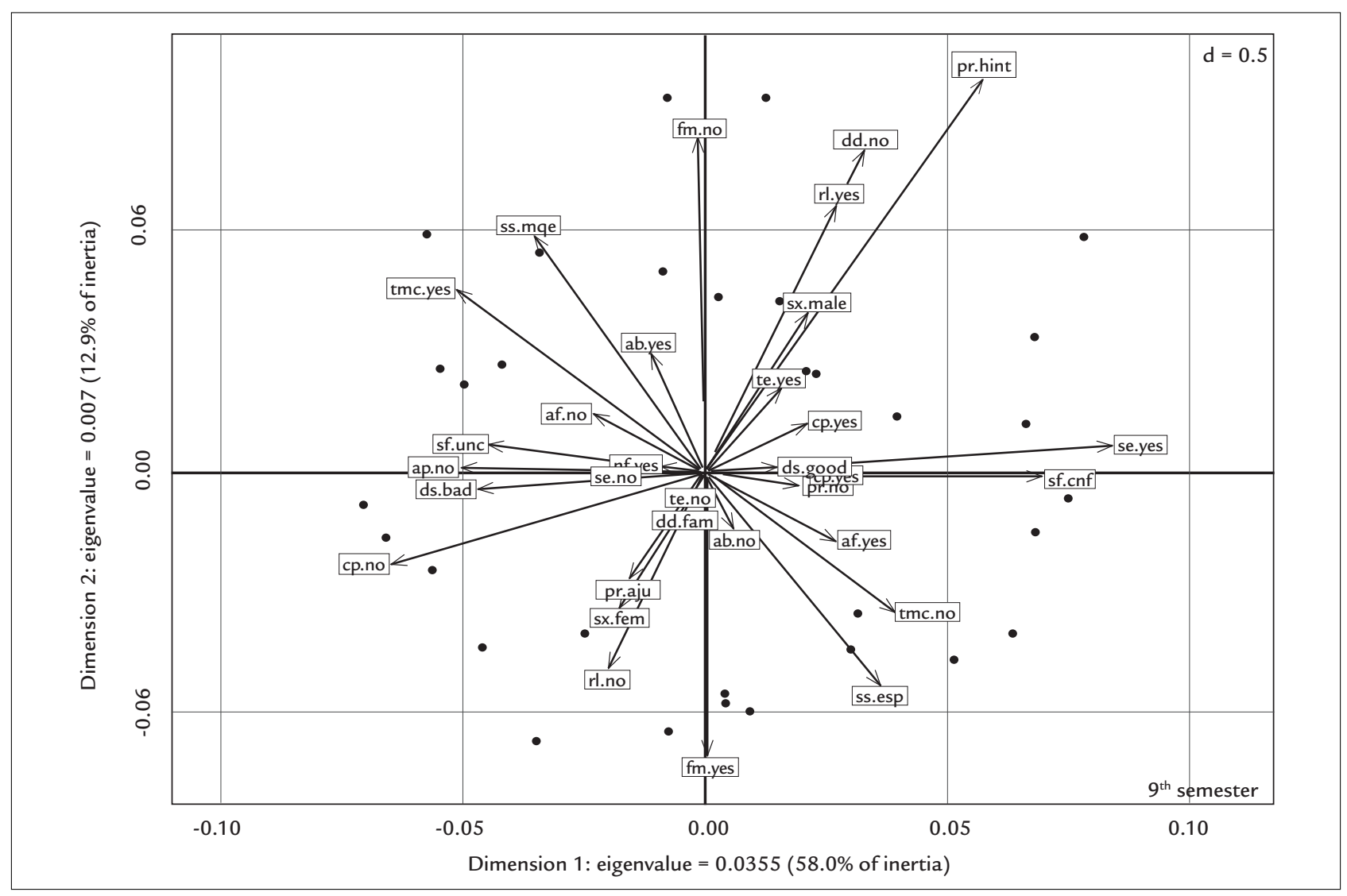

FIGURE 1 Correspondence analysis map: common mental disorders among medical students and associated factor in $5^{\text {th }}$ program year (9 $9^{\text {th }}$ semester). Aracaju, SE - Brazil, 2011.

Outcome variable:

CMD (common mental disorders): yes/no

Variables related to sociodemographic aspects:

$\mathrm{df}$ (doctor in the family): yes/no

pr (place of origin): aju (Aracaju city)/hint (hinterland/others)

rel (religion): yes/no

sp (steady partner): yes/no

sx (sex): fem (female)/male (male)

Variables related to personal aspects:

dd (hares the burden of difficulties with someone): yes/no

es (emotional support):yes/no

fh (feels happy): yes/no

pha (physical activities): yes/no

Variables related to educational process:

ap (academic performance): bad/good

dos (thoughts of dropping out of the university): yes/no

ep (expectations regarding the program): le mqe (program less than they expected)/me (program more than or equal to the expected)

fa (feelings about program activities): uncom dcnf (uncomfortable)/ com cnf (comfortable)

mpsp (medical program as a source of pleasure): yes/no

occ (other occupation): yes/no

ste (satisfaction with teaching strategies): yes/no 
During the internship ( $6^{\text {th }}$ program year), the following variables were associated with CMD: low performance, feeling uncomfortable with the program activities, not being satisfied with the teaching strategies, and feeling that the program is not a source of pleasure (eigenvalues equal to 0.0213 and 0.005 , with corresponding inertia of 48.9 and $13.6 \%$, respectively, for the first and second dimensions) (Figure 1).

A Poisson regression (PR) analysis was performed in the $5^{\text {th }}$ program year, specifically in the $9^{\text {th }}$ semester (the data collection period that corresponds to the six months preceding the internship wherein an increased prevalence of CMD was noted). We intended to verify the associated size of the variables identified in the correspondence analysis map at that time. Thus, we described the adjusted PRs for each variable potentially associated with $\mathrm{CMD}$ : female sex $(\mathrm{PR}=1.38)$, originating from capital cities $(\mathrm{PR}=1.97)$, the program was less than they expected $(\mathrm{PR}=3.20)$, discomfort with program activities $(\mathrm{PR}=2.10)$, dissatisfaction with teaching strategies $(\mathrm{PR}=1.38)$ and feeling that the program is not a source of pleasure $(\mathrm{PR}=2.06)$ being $\mathrm{R} 2=28.8 \%$ and $\mathrm{AIC}=60.04$.

\section{Discussion}

The increased prevalence of CMD identified in our study is consistent with the results of other studies. ${ }^{13,15,19}$

CMD prevalence among the students at the beginning of their program was low and similar to that observed in the general population. This finding was expected because the students answered the questionnaire on the first day of school. However, in the second year, the prevalence of CMD increased. Another longitudinal study also identified this increase and considered the program itself a chronic stressor for the students because the depression rate increased disproportionately throughout the medical program in a non-episodic manner. ${ }^{20}$

Only a minority of the respondents succeeded in their first attempt to enter the medical school through a difficult entry exam. The remaining students repeated the entry exam for three or four years after intense studying to accomplish the long-awaited dream of getting into medical school. Thus, the lack of emotional support reported by freshmen and the social isolation demanded by this rhythm of study, in addition to the expectation of approval, may be responsible for greater physical illness in the first year.

As reported by other researchers, the vast majority of medical students at the beginning of the program "have expectations regarding medical practice and not academic work itself." Therefore, the students want to have contact with patients and to help the suffering people. However, these events do not occur in the first year of the program, when the subjects taught are primarily related to basic sciences, leading to a conflict of interest or even lack of motivation. ${ }^{21}$

In our study, an increase in CMD prevalence, mental disorder diagnoses made by a psychiatrist, emotional stress, dissatisfaction with the program choice, worsening of expectations for the future and thoughts of dropping out of the school, which were noted from the third program year onward, suggest that the process of medical education contributes to these results. Other researchers have demonstrated that the psychological intensity inherent to medical activities may be an important factor for emotional disorders in medical students, medical residents and doctors, who are predisposed or more vulnerable. ${ }^{22,23}$

In some studies assessing medical schools with a traditional curriculum such as ours, the final year appears as a potential stressor. However, other studies indicate that important moments in other phases or transitions in the program are also stressors: the first year, when students first handle a corpse, and the third year, when the Introductory Clinical Cycle begins and patient contact first occurs. In our study, an increased prevalence of CMD is noted in our institution during the fifth program year (semester 9); this period corresponds to the transition to the internship, which begins in the tenth semester. ${ }^{13,24}$ We consider that the CMD prevalence falls in the $6^{\text {th }}$ program year, maybe due to overcoming the internship transition stress as well as to the greater integration of knowledge acquired over the years.

Another study that has assessed throughout the last 21 years the assistance and psycho-educational support service for medical students at São Paulo University (USP) demonstrated that the following has been a good preventive measure to avoid more serious cases: the suicide rate among them diminished 8 times, reaching the same level of the local population. ${ }^{25}$ We cannot compare these results with ours since this kind of service does not exist in our institution.

Based on the correspondence analysis maps and the logistic regression results, we identified that variables potentially associated with CMD occurred mainly in the third year of the medical program onward and were related to the educational process. Additionally, being female and/or the lack of a steady partner and/or not being engaged in physical activities were also identified as critical variables in various program years.

"Originating from the capital" appeared as one of the variables potentially associated with CMD in the fifth year; this finding has been confirmed in several studies 
that characterize urban areas as more stressful due to violence, less solidarity and traffic problems that create difficulties in the fulfillment of schedules etc. ${ }^{26-29}$

Medical students learn from their professors the importance of physical activities and leisure in the prevention of diseases, particularly those related to mental health. However, excessive program loads and the resulting lack of time is the most common excuse for not taking the advice themselves. Instead, students adopt self-medication with psychoactive substances and ilicit drugs, which demand greater effort and time. These activities are more frequently reported among medical students, according to other studies. ${ }^{30,31}$

Our study is not characterized as a cohort study because we chose to use anonymous questionnaires, ensuring that the participants concealed their identities although we followed the group of students for six years with few losses and no new participants. Thus, we were not able to initially identify and exclude those with CMD with the aim of following only the healthy individuals; however, adherence and truthfulness were ensured by this design. It is likely that, if the students were identified, they would not offer authentic responses or may have refused to participate in the study. ${ }^{32}$

Our research has limitations primarily attributable to its design (repeated enquiry cross-sectional survey), since we cannot establish causality to the identified associations once they simultaneously analyze outcome and exposure. However, we proposed hypotheses and identified potential factors associated with the generation of the disorder that can contribute to the establishment of necessary preventive measures in this population and other similar academic communities.

\section{Conclusion}

CMD prevalence increased among respondents in the third year of medical school and increased non-linearly throughout the years. Students in the third and fifth program years were the most affected, and these periods correspond to moments of transition in the program, namely, the Introductory Clinical Cycle and Internship, respectively.

Factors potentially associated with CMD were primarily related to the educational process, which demonstrates that the medical school must reflect critically on their role in the promotion and prevention of these disorders in students.

Further studies in this and other institutions of similar profiles will contribute to the comparison and validation of our results.
Finally, the results show that preventive measures should be implemented, such as establishing psychoeducational support services for students and professors and revising the educational process to minimize the losses provoked by the development of CMD.

\section{Conflict of interest}

The authors declare no conflict of interest.

\section{Resumo}

Transtorno mental comum em estudantes de medicina: Estudo transversal por inquéritos repetidos durante seis anos

Introdução: Tornar-se médico é um processo bastante complexo. Fatores relacionados a personalidade do aluno, processo educacional e experiência diária com dor e morte contribuem para vivências psicoemocionais peculiares, nem sempre devidamente investigadas durante a formação médica.

Objetivo: Estimar a prevalência de transtornos mentais comuns (TMC) e fatores associados durante os seis anos de graduação entre todos os estudantes de uma turma de medicina de uma universidade pública brasileira.

Método: Estudo transversal por inquéritos repetidos. Todos os 40 alunos admitidos em 2006 na escola médica pesquisada foram incluídos no estudo e avaliados anualmente até 2011 através do SRQ-20 e de um questionário estruturado elaborado pelos autores sobre aspectos sócio-demográficos, pessoais e educacionais. Realizadas regressão logística e análise de correspondência.

Resultados: Os 40 calouros na primeira avaliação tinham média de idade de 20 anos ( $D P=2,4$ ), sendo $57,5 \%$ do sexo feminino e $41 \%$ aprovados no terceiro vestibular. A prevalência TMC aumentou ao longo do curso: de 12,5\% no primeiro ano para $43,2 \%$ no quinto. As seguintes variáveis foram potencialmente associadas à TMC no quinto ano: sexo feminino $(\mathrm{RP}=1,38)$, originários de capitais $(\mathrm{RP}=1,97)$, achar o curso menos do que esperava $(\mathrm{RP}=3,20)$, ter desconforto com as atividades do curso $(\mathrm{RP}=2,10)$, estar insatisfeito com estratégias de ensino $(\mathrm{RP}=1,38)$ e sentir que o curso não é fonte de prazer $(\mathrm{RP}=2,06)$ sendo $\mathrm{R} 2=28,8 \%$ e $\mathrm{AIC}=60,04$.

Conclusão: Fatores potencialmente associados com alta prevalência de TMC foram relacionados à formação médica, mostrando que é necessário implementar medidas preventivas e revisão do processo educacional no intuito de reduzir os danos causados pelo desenvolvimento de TMC.

Palavras-chave: transtornos mentais, estudantes de medicina, saúde mental, educação médica, saúde ocupacional. 


\section{REFERENCES}

1. Ghosh JM. Unexplained somatic symptoms--diagnostic window for mental disorders. J Indian Med Assoc. 2006; 104(5):255-60.

2. Mari JJ, Williams P. A validity study of a psychiatric screening questionnaire (SRQ-20) in primary care in the city of Sao Paulo. Br J Psychiatry. 1986; 148:23-6.

3. Goldberg DP, Huxley P. Common mental disorders a bio-social model. London: Tavistock/Routledge; 1992.

4. Lima MS, Beria JU, Tomasi E, Conceição AT, Mari JJ. Stressful life events and minor psychiatric disorders: an estimate of the population attributable fraction in a Brazilian community-based study. Int J Psychiatry Med. 1996; 26(2):211-22.

5. Ludermir AB, Lewis $\mathrm{G}$. Investigating the effect of demographic and socioeconomic variables on misclassification by the SRQ- 20 compared with a psychiatric interview. Soc Psychiatry Psychiatr Epidemiol. 2005; 40(1):36-41.

6. Gonçalves DA, Mari JJ, Bower P, Gask L, Dowrick C, Tófoli LF, et al. Brazilian multicentre study of common mental disorders in primary care: rates and related social and demographic factors. Cad Saúde Pública 2014; 30(3):623-32.

7. Finger G, Silva ER, Falavigna A. Use of methylphenidate among medical students: a systematic review. Rev Assoc Med Bras. 2013; 59(3):285-9.

8. Baldassin S, Silva N, de Toledo Ferraz Alves TC, Castaldelli-Maia JM, Bhugra D, Nogueira-Martins MC, et al. Depression in medical students: cluster symptoms and management. J Affect Disord. 2013; 150(1)110-4.

9. Costa EF, Santana YS, Santos AT, Martins LA, Melo EV, Andrade TM. [Depressive symptoms among medical intern students in a Brazilian public university]. Rev Assoc Med Bras. 2012; 58(1):53-9.

10. Costa EF, Santos SA, Santos AT, Melo EV, Andrade TM. Burnout syndrome and associated factors among medical students: a cross-sectional study. Clinics. 2012; 67(6):573-80.

11. de Abreu Santos AT, Grosseman S, de Oliva Costa EF, de Andrade TM. Burnout syndrome among internship medical students. Med Educ. 2011; 45(11):1146.

12. Benvengnú LA, Deitos F, Copette FR. Problemas psiquiátricos menores em estudantes de medicina da Universidade Federal de Santa Maria, RS. Rev Psiquiatr Rio Gd Sul. 1996; 18(3):229-33.

13. Costa EF, Andrade TM, Silvany Neto AM, Melo EV, Rosa AC, Alencar MA, et al. Common mental disorders among medical students at Universidade Federal de Sergipe: a cross-sectional study. Rev Bras Psiquiatr. 2010; 32(1):11-9.

14. Facundes VL, Ludermir AB. Common mental disorders among health care students. Rev Bras Psiquiatr. 2005; 27(3):194-200.

15. Lima MC, Domingues MS, Cerqueira AT. [Prevalence and risk factors of common mental disorders among medical students]. Rev Saúde Pública. 2006; 40(6):1035-41.

16. Harding TW, de Arango MV, Baltazar J, Climent CE, Ibrahim HH, LadridoIgnacio L, et al. Mental disorders in primary health care: a study of their frequency and diagnosis in four developing countries. Psychol Med. 1980; $10(2): 231-41$.
17. R Development Core Team. R: A Language and Environment for Statistical Computing [computer program]. Vienna, Austria: R Foundation for Statistical Computing; 2011.

18. Barros AJ, Hirakata VN. Alternatives for logistic regression in cross-sectional studies: an empirical comparison of models that directly estimate the prevalence ratio. BMC Med Res Methodol. 2003; 3:21.

19. Smith CK, Peterson DF, Degenhardt BF, Johnson JC. Depression, anxiety, and perceived hassles among entering medical students. Psychol Health Med. 2007; 12(1):31-9.

20. Rosal MC, Ockene IS, Ockene JK, Barrett SV, Ma Y, Hebert JR. A longitudinal study of students' depression at one medical school. Acad Med. 1997; 72(6):542-6.

21. Azevedo GA, Tollendal CB, Nogueira DG, Bartels FP, Paula FC, Beraldo FMM. Factors that guide the choice of the medical course. Rev Bras de Educo Méd. 2005; 29(3):157-226. Available from: http://educacaomedica. org.br/UserFiles/File/2005/volume29_3/fatores_orientam.pdf.

22. Haglund ME, aan het Rot M, Cooper NS, Nestadt PS, Muller D, Southwick $\mathrm{SM}$, et al. Resilience in the third year of medical school: a prospective study of the associations between stressful events occurring during clinical rotations and student well-being. Acad Med. 2009; 84(2):258-68.

23. Nogueira-Martins LA, Fagnani NR, Macedo PC, Citero VA, Mari JJ. The mental health of graduate students at the Federal University of Sao Paulo: a preliminary report. Braz J Med Biol Res. 2004; 37(10):1519-24.

24. Millan L, De Marco O, Rossi E, Arruda P. O universo psicológico do futuro médico: vocação, vicissitudes e pespectivas. São Paulo: Casa do Psicólogo; 1999

25. Millan LR, Arruda PC. [Psychological assistance to medical students: 21 years of experience]. Rev Assoc Med Bras. 2008; 54(1):90-4.

26. Fortes S, Villano LA, Lopes CS. Nosological profile and prevalence of common mental disorders of patients seen at the Family Health Program (FHP) units in Petropolis, Rio de Janeiro. Rev Bras Psiquiatr 2008; 30(1):32-7.

27. Anselmi L, Barros FC, Minten GC, Gigante DP, Horta BL, Victora CG [Prevalence and early determinants of common mental disorders in the 1982 birth cohort, Pelotas, Southern Brazil]. Rev Saúde Pública 2008; 42(Suppl 2):26-33

28. Cohidon C, Imbernon E, Gorldberg M. Prevalence of common mental disorders and their work consequences in France, according to occupational category. Am J Ind Med. 2009; 52(2):141-52.

29. Schmidt MI, Duncan BB, Azevedo e Silva G, Menezes AM, Monteiro CA Barreto SM, et al. Chronic non-communicable diseases in Brazil: burden and current challenges. Lancet. 2011; 377(9781):1949-61.

30. Romero MI, Santander J, Hitschfeld MJ, Labbe M, Zamora V. [Illicit and psychotropic drug use among medical students at the Pontificia Universidad Católica de Chile]. Rev Med Chil. 2009; 137(4):459-65.

31. Habibzadeh A, Alizadeh M, Malek A, Maghbooli L, Shoja MM, Ghabili K. Illicit methylphenidate use among Iranian medical students: prevalence and knowledge. Drug Des Devel Ther. 2011; 5:71-6.

32. Levine RE, Breitkopf CR, Sierles FS, Camp G. Complications associated with surveying medical student depression: the importance of anonymity. Acad Psychiatry. 2003; 27(1):12-8. 


\section{ERRATUM}

http://dx.doi.org/10.1590/1806-9282.63.12.1104

In the article "Common mental disorders in medical students: A repeated cross-sectional study over six years", DOI: http://dx.doi.org/10.1590/1806-9282.63.09.771, published in the journal Rev Assoc Med Bras, 63(9):771-778, on page 771, where it reads:

"We performed logistic regression and correspondence analysis."

Change to:

"We performed Poisson regression and correspondence analysis."

On page 777 , where it reads:

"Realizadas regressão logística e análise de correspondência."

Change to:

"Realizadas regressão de Poisson e análise de correspondência." 